In the situation of the principal case, with no judicial equivalent of an eminent domain procedure available to alleviate the necessity of finding that the surface owner has either an unqualified right or no right at all to drill through the coal, ${ }^{15}$ it is not strange to find the Indiana court resorting to an arbitrary distinction between water and oil or gas in its attempt to balance the competing interests. The court was unwilling to give general application to a rationale evoked by a concern for the oil and gas industries of Pennsylvania ${ }^{16}$ - the equivalent of finding for the surface owner in Pyramid Coal Co. v. Pratt.

\title{
"PUBLIC INTEREST" AND THE MARKET IN COLOR TELEVISION REGULATION*
}

Color television is not a new idea in the history of television and the problem had been before the Federal Communications Commission as early as I940. The Commission considered various color television systems in public hearings in I94I, I944-45, and between December 3, I946 and February I3, I947, but refused to adopt commercial standards for any of the systems demonstrated because they were unsatisfactory. On July II, I949 the Commission issued a notice of further proposed rule-making relative to color television. ${ }^{2}$ The color television systems which the Commission proposed to examine had to meet two criteria: ( $\mathrm{I}$ ) that they operate in a six megacycle channel and (2) that the pictures could be received on existing black and white television receivers

Atl. I7 (I888); Tramonte v. Colarusso, 256 Mass. 299, I52 N.E. go (1926). The doctrine has not been extended to intentional, or negligent, crossing of property lines. Curtis $\mathrm{Mfg}$. Co. v. Spencer Wire Co., 203 Mass. 448, 89 N.E. 534 (Igo9); Szathmary v. Boston \& A. R. Co., 214 Mass. 42, I00 N.E. IIO7 (rg03); Kershishian v. Johnson, 210 Mass. I35, 96 N.E. 56 (IgIr). In other cases of intentional trespass, where the loss to the defendant would be exceptional and that to the plaintiff negligible, equity has denied an injunction. Crescent Mining Co. v. Silver King Mining Co., I7 Utah 444, 54 Pac. 244 (I898); McCann v. Chasm Power Co., 2II N.Y. 30x, I05 N.E. 4 I6 (I9I4).

Is For "balancing the equities" to be applicable, the coal owner would have to be seeking an injunction against drilling by the surface owner. Even then the doctrine has not been employed where there was substantial injury caused by intentional trespass. Barker v. Mintz, 73 Colo. 262, 215 Pac. 534 (r923), and Whiles v. Grand Junction Mining \& Fuel Co., 86 Colo. 4I8, 282 Pac. 260 ( $x 929)$ relied upon a statute which provided that a surface owner could enjoin the mineral owner from mining unless the latter gave the former a bond to secure him against injury.

${ }^{16}$ In Pennsylvania Central Brewing Co. v. Lehigh Valley Coal Co., 250 Pa. 300 , 95 Atl. 47I (I9I5), the Pennsylvania court did extend the Chartiers Coal decision to subterranean water.

I FCC, First Report of Commission, Color Television Issues, IT 7-2r (r950) (mimeographed). (The First Report of Commission, Color Television Issues will hereinafter be cited as "First Report.")

2 FCC, Television Broadcast Service, Notice of Further Proposed Rule Making, I4 Fed. Reg. 4483 (I949).

* Since this issue went to press, the Supreme Court has handed down its decision in the current case. Radio Corp. of America v. United States, 19 U.S. L.W. 4337 (May 29, 195I). As suggested in this Comment the lower court decision was affirmed. Justice Frankfurter dissented on substantive grounds. 
"simply by making relatively minor modifications in such existing receivers." Following the close of the hearings, the Commission would "adopt such rules, regulations and standards, as will best serve public interest, convenience or necessity." 4

The hearings began September 26, 1949 and ended May 26, I950. Systems of color television transmission were submitted by Columbia Broadcasting System, Radio Corporation of America, and Color Television Incorporated. The Commission heard witnesses, received exhibits and made extensive field tests concerning the three proposed systems. On September I, I950 the Commission issued its First Report in which it found the RCA ${ }^{5}$ and $\mathrm{CTI}^{6}$ systems unsatisfactory, and the CBS system satisfactory. ${ }^{7}$ The CBS system was not adopted at that date because it was not compatible with existing black and white television receivers, i.e., its color transmissions could not be received over existing television receivers, without some adjustment of the receivers, as black and white pictures. ${ }^{8}$ The Commission was faced with a dilemma. It would have liked a system that was compatible but the compatible RCA system did not work satisfactorily. If the Commission waited, the problem of compatibility would become aggravated because black and white receivers, incompatible with CBS color transmissions, were being sold at a high and rapidly increasing rate. If compatibility turned out to be impossible in the foreseeable future, the problems an incompatible system would face would be even greater.

The Commission attempted to avoid this dilemma in its First Report ${ }^{9}$ by not adopting final commercial standards for the CBS system at that time. Instead, the Commission issued a second notice ${ }^{\mathrm{r} o}$ of further proposed rule-making in which it suggested that television sets be constructed which could receive either existing black and white transmissions or CBS color transmissions in black and white. ${ }^{\mathrm{Ix}}$ By definition the new sets would receive RCA compatible color transmissions in black and white. The manufacturers, asked to submit their comments by September 29, I950 on the feasibility of the Commission's proposal, ${ }^{x_{2}}$ apparently generally agreed that it would be a difficult engineering problem to incorporate such specifications-the so-called "bracket standards" -into the manufacture of television receivers and that this might take some considerable time. ${ }^{x 3}$

RCA filed a petition on October 4, I950 asking the Commission to consider 3 Thid., at App. A II C.

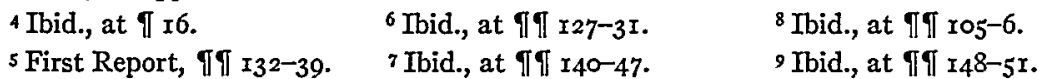

ro FCC, Television Broadcast Service, Notice of Further Proposed Rule Making, I5 Fed. Reg. 6047 (I950).

II First Report, 1 II I5I, I53. $x 2$ Ibid., at $T$ I 5 I.

${ }_{3}$ FCC, Second Report of the Commission [on Color Television], 8 (1950) (mimeographed). ('The Second Report of the Commission will hereinafter be cited as "Second Report.") See also excerpts from comments submitted to Commission re bracket standards, Plaintiff's Reply Brief, Annex C, Radio Corp. of America v. United States, 6 Pike and Fischer Radio Regulation 2073 (1950). (The Pike and Fischer Radio Regulation service will hereinafter be cited as RR.) 
improvements made in the RCA system of color transmission and reception in the period between December 5, I950 and January 5, I95I. RCA also asked that the Commission view further special broadcasts of the three proposed color systems during the period to June 30 , I95 I before reaching a final determination with respect to color standards. ${ }^{\mathrm{I}}$ The Commission refused these requests and on October Io, I950 issued its Second Report adopting the CBS system of color transmission; simultaneously it issued an order amending the commission's standards of good engineering practice to provide for standards of commercial color television transmission ${ }^{\mathrm{Ts}}$ in accordance with the CBS system. The order was to become effective November 20, I950. The current suit ${ }^{16}$ was brought by RCA to enjoin and set aside the FCC order of October Io, I950. On December 20 , I950 a statutory ${ }^{x 7}$ three-judge court decided that within the limited review of administrative decisions ${ }^{88}$ there was no basis for upsetting the Commission's order. The court granted the FCC motion for a summary judgment and RCA appealed. ${ }^{19} \mathrm{~A}$ temporary restraining order was granted to remain effective until April I, I95I or until terminated by the Supreme Court. ${ }^{20}$

The most important RCA contention is that an incompatible system is bad because the audience will be limited to those whose sets either have been adapted to receive CBS color in black and white or have been converted or built to receive CBS color in color. A compatible system would have a much larger audience during the economically important transition period, while the small audience available to an incompatible system would make it uneconomic to transmit expensive programs at expensive hours. ${ }^{2 x} \mathrm{RCA}$ has emphasized the large obsolescence loss to the twelve million present set owners. ${ }^{22} \mathrm{RCA}$ has also made many technical engineering objections to the FCC decision. ${ }^{23}$

${ }^{2} 4$ FCC, Television Broadcast Service, Order Denying Petition for Review of Further TV Demonstrations, I5 Fed. Reg. 6936 (I950).

${ }^{x 5}$ FCC, Radio Broadcast Service, Standards of Good Engineering Practice Concerning Television Broadcast Stations, I5 Fed. Reg. 7013 (1950).

${ }^{26}$ Radio Corp. of America v. United States, 6 RR 2073 (1950). (I950),

${ }_{77} 62$ Stat. 968 (I948), 28 U.S.C.A. $\S 2284$ (I950); 62 Stat. 970 (I948), 28 U.S.C.A. $§ 2325$

${ }^{8}$ Radio Corp. of America v. United States, 6 RR 2073, 2076 (1950). See American Telephone and Telegraph Co. v. United States, 299 U.S. 232, 236 ( $x_{936)}$; Federal Security Administrator v. Quaker Oats Co., 3 I8 U.S. 2I8, 227 (x943); National Broadcasting Co. v. United States, 3 I9 U.S. I90, 224 (1943).

19 Radio Corp. of America v. United States, Supreme Court of the United States, October Term, I950, No. 565 . The appeal was taken directly to the Supreme Court as provided by statute. 62 Stat. 926 (1948), 28 U.S.C.A. \$ I253 (I949).

${ }^{20}$ The Supreme Court has heard the oral arguments in the case and has extended the temporary restraining order "pending issuance of the mandate of this Court." 7I S.Ct. 574 (March 27, x95x).

ax Reply to Motion to Affirm at 3, Radio Corp. of America v. United States, Supreme Court of the United States, October Term, I950, No. 565 .

22 Ibid., at 6-Io.

${ }^{23} \mathrm{RCA}$ contends that geometric resolution (the term for the number of picture elements which contribute to the detail of a television image) on the CBS system is poorer than under 
The FCC and CBS admit that the CBS system is incompatible. ${ }^{24}$ The FCC contends, however, that the RCA system does not work satisfactorily at present, that it may never work satisfactorily, and that meanwhile the problem of incompatibility becomes worse because more incompatible black and white receivers are being sold every month. ${ }^{25}$ Incompatibility in present receivers can be overcome at a price: present minimum estimates are about $\$ 50$ to adapt existing sets to receive CBS color in black and white, and about \$roo in addition to convert them to receive CBS transmissions in color. ${ }^{26}$ The FCC and CBS have also replied that, although RCA color is theoretically compatible and there is no difficulty about adaptation of existing receivers, no figures have

present black and white standards. RCA also claims that the CBS system uses a mechanical color wheel in the transmission and reception of the color image. The main objection to the mechanical color wheel is that it limits the size of a direct view picture to $12 \frac{11}{2}$ " while most present direct view pictures in black and white are $16^{\prime \prime}$ and over. Another objection made to the CBS system is that the image flickers in an annoying manner unless the brightness of the screen is reduced considerably below the level of brightness attainable in present black and white images. Reply to Motion to Affirm at I3, Radio Corp of America v. United States, Supreme Court of the United States, October Term, r950, No. 565 .

The FCC admits that the CBS color picture has less geometric resolution (picture elements) than present black and white, or the proposed RCA system, which has the same geometric resolution as present black and white, but it contends that color adds an additional visual impression of detail which more than compensates. The black and white picture which an adapted receiver would get of CBS color transmissions would of course suffer from this lack of detail without the additional compensation of color. Brief for the Government at 34-36, Radio Corp. of America v. United States, 6 RR 2073 (I950). The FCC claims that the addition of color will more than compensate for the loss in size of the direct view screen. It is also claimed that the CBS system is not permanently limited to the color wheel method of transmission and reception because this is not a fundamental part of the theoretical basis of the CBS system. If RCA successfully develops a completely electronic tri-color tube for receivers, this tube can be used on the CBS system in place of the color wheel and size limitations would then be eliminated. Brief for the Government at 36-37, Radio Corp. of America v. United States, 6 RR 2073 (I950); Second Report, I I2. The FCC contends that CBS flicker is not objectionable at a level of brightness which is suitable for home use. They also claim that there are several improvements in technique which may soon be available which will increase brightness without also increasing flicker. Brief for the Government at 33-34. Radio Corp. of America v. United States, 6 RR 2073 (r950); First Report, ๆf 66, 67, 74, 142.

RCA also claims that the FCC employed a biased engineer in the hearings. The engineer had invented an apparatus which was used in the CBS system and although he had given up any monetary interest in his invention in accordance with FCC rules, he still had a prestige interest in the success of the CBS system. Reply to Motion to Affirm at:32-33, Radio Corp. of America v. United States, Supreme Court of the United States, October Term, I95०, No. 565 . The FCC answer to the biased engineer contention is that RCA did not make any objection to the engineer's continued participation in the hearings at any time during the hearings although RCA did object once to his testifying about his own invention. Brief for the Government at 56-60, Radio Corp. of America v. United States, 6 RR 2073 (I950).

${ }^{24}$ Brief for the Government at 37-38, Radio Corp. of America v. United States, 6 RR 2073 (1950); Memorandum of Columbia Broadcasting System, Defendant-Intervenor, ibid., at 18-22.

${ }^{25}$ Brief for the Government at 5-8, 40-4I, Radio Corp. of America v. United States, 6 RR 2073 (1950); First Report, TI 149.

${ }^{26}$ First Report, IT I05-6. 
been given by RCA on the cost of converting existing sets to receive RCA transmissions in color. ${ }^{27}$

The FCC makes many positive contentions to justify its acceptance of the CBS system. The color fidelity of the CBS system is good, while RCA's is not satisfactory ${ }^{28}$ (color fidelity is the ability of a system to transmit realistic copies of the colors in the original scene). It is also claimed that CBS's picture texture is good and RCA's is not satisfactory ${ }^{29}$ (picture texture is essentially a measure of the effectiveness with which the three primary colors used in transmission combine to form the various colors of the original scene without misregistration and color breakup and fringing). The FCC also claims that the CBS system has successfully undergone field testing and the RCA system has not; ${ }^{30} \mathrm{CBS}$ transmission and reception equipment is simpler, less expensive and easier to operate than that of RCA; ${ }^{3 x}$ the CBS system is freer from electric interference than the RCA system;32 CBS color can be transmitted over existing network facilities but there was no proof at the hearings that this is also true of the RCA system. ${ }^{33}$ But to all of this, RCA claims that the Commission was remiss in its refusal to consider all pertinent information available on the merits of the three transmission systems, ${ }^{34}$ and that the Commission should have (I950).

${ }^{27}$ Brief for the Government at 40-42, Radio Corp. of America v. United States, 6 RR 2073

${ }^{28}$ Brief for the Government at 2I-25, 32-33, Radio Corp. of America v. United States, 6 RR 2073 (I950); First Report, II 82, 86, 87, I32, I40.

29 Brief for the Government at $25-28,33$, Radio Corp. of America v. United States, 6 RR 2073 (I950); First Report, III 81, 83, 94, 97, I33, 440.

${ }^{30}$ Brief for the Government at 3I, Radio Corp. of America v. United States, 6 RR 2073 (I950); First Report, II I38.

3I Brief for the Government at 30-3I, Radio Corp. of America v. United States, 6 RR 2073 (I950); First Report, TII III, II2, II6-I8, I34, I35, I4I.

${ }^{32}$ Brief for the Government at 29, Radio Corp. of America v. United States, 6 RR 2073 (I950); First Report, IT Ior, 136 .

${ }^{33}$ Brief for the Government at 29, 36, Radio Corp. of America v. United States, 6 RR 2073 (I950); First Report, II II 4 , II9, I37.

34 RCA has emphasized the fact that the FCC did not include the "Condon Report" in

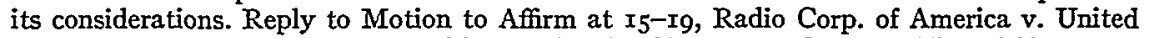
States, Supreme Court of the United States, October Term, I950, No. 565. The FCC's answer to this contention is that the "Condon Report" was not part of the official record made before the FCC during the hearings. Reply Brief of Defendants at 4, Radio Corp. of America v. United States, 6 RR 2073 (I950). The "Condon Report" was prepared by the Senate Advisory Committee on Color Television under the chairmanship of Dr. E. U. Condon, Director of the National Bureau of Standards. Sen. Doc. No. I97, 8ist Cong. 2d Sess. (I950). The report was also printed in 38 Proceedings of the Institute of Radio Engineers 980 (r950), and all citations will be to the proceedings of the I.R.E. The Committee worked independently of the FCC and was composed of five eminent electrical engineers and physical scientists, including Dr. Condon. 38 Proceedings of the I.R.E. 980 (I950). The report was released July IO, x950, several months before the FCC released its First Report. The Condon Committee was in general more favorable than the FCC to the RCA system of color transmission. The reason for this difference seems to be mainly the result of a difference in point of view. The Condon Committee was much more disposed to be generous about present flaws in a system of trans- 
reopened the hearings and suspended its order until June, I95 to give RCA an opportunity to exhibit its improved system. ${ }^{35}$

The most interesting question in this litigation is whether the FCC should have permitted both the CBS and the RCA systems to operate at once, with the public acting as final judge. The three-judge court did not discuss this question because it involved a consideration of the wisdom of the FCC decision, and there is a good chance that the Supreme Court will take the same course. ${ }^{36}$ The basic premise of the FCC decision is that a system of multiple engineering standards is not suitable for the successful operation of commercial broadcasting. ${ }^{37}$ This premise apparently has been widely accepted as obvious on its face $3^{38}$ RCA attacked it ${ }^{39}$ only after the CBS system had been accepted.

A good argument can be made that instead of being "arbitrary and capri-

mission and to place much greater emphasis on the long run theoretical possibilities inherent in such a system. The Committee was particularly impressed by the considerable technical ingenuity with which the RCA system solved the problem of transmitting a maximum amount of "information" within the given six megacycle channel width. The Committee, for the same reasons, was in many ways more generous than the FCC about the CBS system, e.g., the Committee treated the mechanical color wheel difficulty in the CBS system and the limited size of the CBS direct view screen as temporary problems which were not fundamental in the system. A fair summary of the Committee's conclusions would be that CBS had made the groatest amount of progress in the perfection of a system with relatively limited theoretical possibilities, and that RCA had as yet made less progress in the development of a system with greater inherent theoretical possibilities. 38 Proceedings of the I.R.E., 980, 996 (I950).

${ }_{35}$ Reply to Motion to Affirm at I5 $^{-22}$, Radio Corp. of America v. United States, Supreme Court of the United States, October Term, I950, No. $5^{6} 5$.

${ }^{36}$ See note $x 8$ supra.

${ }^{37}$ In a previous report on television transmission standards the Commission stated: "Such standards as a practical matter must require a fair degree of efficiency and assure to the public in basic outline a single uniform system of broadcasting which will enable every transmitting station to serve every receiver within its range." Report of the Commission in the Matter of Order No. 65 Setting Television Rules and Regulations for Further Hearing, Docket No. 5806, at 2 (May 28, 1940). See Reply to Motion to Affirm at 6-7, Radio Corp. of America v. United States, Supreme Court of the United States, October Term, I950, No. 565 .

${ }^{38} \mathrm{Mr}$. Rosenman, the CBS counsel, was asked during oral argument by Justices Frankfurter and Black whether the FCC decision had set limits on scientific development. Mr. Rosenman replied that he was sure the FCC had not "closed the door" to new techniques in color television transmission, but he was "surprised" at the RCA suggestion that the Commission should have approved more than one system because "that would be asking people to make up their minds, when they bought color television sets, what broadcast they intend to get; the set wouldn't work for all stations." N.Y. Times, p. 4I, col. 2 (March 27, 195I).

39 RCA's position on the desirability of multiple standards is not consistent. When arguing that only a compatible system is desirable, a basic premise of RCA's argument is that multiple standards are undesirable. Reply to Motion to Affirm at 6-io, Radio Corp. of America v. United States, Supreme Court of the United States, October Term, I950, No. 565. But when arguing that RCA's system should be permitted to operate in competition with the CBS system, RCA argues that competition between methods of transmission should be permitted. Ibid., at 22-25. One justification of this inconsistency may be the RCA argument that a compatible system is really not a new method of transmission since it can be received by existing sets and therefore only adds a "plus" to broadcast signals so that sets which can utilize it will receive the transmissions in color. Ibid., at 23 . 
cious" or having neglected the "public interest" as RCA has contended, $4^{\circ}$ the Commission took its responsibility most seriously, but within the framework of a limited and unwieldy conception of the standard of "public interest." The choice of a method of color television transmission by an administrative commission is an extremely formidable problem and involves predictions about the course of scientific development in the foreseeable future and about public behavior when confronted with new choices. An interpretation of the standard of "public interest" which did not involve an administrative agency in making this decision, and which was consistent with current views about the best organization of economic life, would have very much to recommend it indeed.

I

Congress passed "An Act to Regulate Radio Communication" ${ }_{42}$ in I9I2. This first attempt at comprehensive federal regulation of radio communication was not repealed until $1927^{43}$ - well into the period of development of commercial radio broadcasting. The act was administered by the Secretary of Commerce and Labor who was to issue licenses to applicants. The main requirements of the act were that the applicant for a license be a United States citizen or corporation and that the license should state the wave length authorized for use.44 There was no explicit recognition that the total number of applicants might exceed the total number of channels available and that some system of allocating channels among applicants had to be devised.

The Secretary of Commerce and Labor did begin a system of allocation of channels among applicants through the licensing power, but the courts refused to follow in extending the scope of the statute. 45 Finally, after the Attorney General gave his opinion that the Secretary had no power to allocate frequency channels, ${ }^{46}$ all attempts at such allocation were abandoned. There was considerable discontent with this state of affairs in the radio industry. Often more than one station operated on the same frequency, or on frequencies not far enough apart, causing interference between stations. ${ }^{47}$ Congress passed the Radio Act

40 Ibid., at ro.

${ }^{4}$ See note $5 x$ infra.

${ }_{42} 37$ Stat. 302 (I9I2).

${ }^{43} 44$ Stat. II62-74 (r927).

4437 Stat. 302 ( 1912$)$.

45 In Hoover v. Intercity Radio Co., 286 Fed. 1003 (App. D.C., x923), the court upheld an order to issue a writ of mandamus requiring that the Secretary of Commerce and Labor issue a broadcasting license although it was shown that at the time there was no available frequency to assign to the applicant without causing interference with other broadcasters. Several years later, in United States v. Zenith Radio Corp., I2 F. 2d 614 (N.D. Ill., I926), the court held that the Secretary had no power at all to assign frequencies.

${ }_{46}^{6} 35$ Ops. Att'y Gen. x26 (x926).

47 Davis, The Law of the Air, in The Radio Industry I56, $166-17 \mathrm{I}$ (1928); White, The American Radio I28-30 (1937). 
of $1927^{48}$ to overcome these difficulties. The Act provided for a Federal Radio Commission with the power to license frequency channels on the basis of the "public interest, convenience, or necessity." ${ }^{9} 9$ This phrase was taken primarily from state and federal public utility regulation. ${ }^{\circ}$ The Communications Act of $\mathrm{r} 934$, which is the basis of present regulation, re-enacted the standard of "public interest, convenience, or necessity."

The inadequacy of the concept of the FCC as a policeman, only regulating to avoid traffic congestion in the frequency channels, was revealed by the history of the Act of rgr2. The most important function of radio regulation is the allocation of a scarce factor of production-frequency channels. The FCC has to determine who will get the limited number of channels available at any one time. This is essentially an economic decision, not a policing decision. The solution of the FCC (and its predecessor, the Federal Radio Commission) to this problem was regulation by government fiat under the standard of "public interest, convenience, or necessity." This choice tended to obscure the fact that economic decisions were being made, because allocation by government fiat seems to grow naturally from the policeman's function; even more important, it tended to obscure the fact that economic decisions could be made another way.

The term "public interest, convenience, or necessity" is general enough to include single or multiple standards, whichever does in fact better serve the public interest, convenience, or necessity. There has never been a Supreme Court decision on multiple standards under the Act, ${ }^{52}$ but the fact that a single standard has been sanctioned by the Court does not preclude the possibility that multiple standards can be brought within the language of the Act. In public utility legislation the general standard of "public interest, convenience, or necessity" has been held to justify the elimination of competition. The justifica-

${ }^{8} 44$ Stat. II62-74 (I927).

49 Ibid.

${ }^{50}$ Senator Dill, floor manager of the legislation, said during debate: "In this proposed law, however, we have laid down a basic principle-namely, the principle of public interest, convenience, and necessity - which is the general legal phrase used regarding all public utilities engaged in interstate commerce." 68 Cong. Rec. 3027 (1927). Consult Davis, op. cit. supra note 47 , at $173-74$.

${ }^{51} 48$ Stat. ro82, 1083, ro85, 1086, ro89 (1934), as amended, 47 U.S.C.A. $\$ \S 303$, 307 (a), $390(a), 312$ (b), 319 (a) (Supp., 1950). Section 303 is the most important in this connection and describes the powers and duties of the Commission.

$5^{2}$ In its argument for competition between standards, RCA relies on Federal Communications Commission v. Sanders Bros. Radio Station, 309 U.S. 470 (I940). Reply to Motion to Affirm at 24-25, Radio Corp. of America v. United States, Supreme Court of the United States, October Term, $x_{95}$, No. 565 . The case involved the question of competition between stations in the same area and not competition between methods of transmission, but the case did at least indicate that the Supreme Court thought that the phrase "public interest, convenience, or necessity" need not have the same consequences under the Communications Act as in public utility legislation. See note 53 infra. 
tion for this policy in public utility regulation is that the industries subject to regulation are decreasing cost industries. A single company operating in a given area is capable of giving the consumer the same service at a lower cost than several competing companies because the average cost of the company decreases as the amount of service it provides increases. It is argued that this would make the trend toward a monopoly in a single firm inevitable and therefore leave the consumer vulnerable to whatever price policies are in the monopolistic firm's best interest. ${ }^{33}$ But it has never been argued that there are economies of scale in broadcasting sufficient to justify a broadcasting monopoly. The British, who do have a broadcasting monopoly in one company, have never justified it on this ground. 54 The arguments for a single company in the public utility field are entirely different from the arguments for a single standard in broadcasting.

The shortage of frequency channels alone need not determine whether one engineering standard for all color television transmission is better than multiple standards. Even if multiple standards are permitted, the FCC can still regulate the use of frequency channels by issuing licenses. The fact that licensees may use different systems of transmission will make no difference with respect to the natural shortage of channels, so long as interference between frequency channels is avoided. The width of each channel can be determined by the FCC as before, and licensees using the different methods of transmission will have to accept the channel width as a given and unvariable condition within which standards must be worked out.

The possibility of multiple standards raises in an explicit form the question of how economic allocation in broadcasting regulation could be determined. If multiple standards are adopted, there are two possible solutions available. Multiple standards can be determined within the framework of regulation by government fiat. The FCC can pass on the economic and engineering adequacy of the transmission standards proposed by prospective licensees instead of setting only one general standard for all licensees as at present. This would introduce some elements of free consumer choice into the framework of existing regulation. The consumer would be able to choose between the various standards sorted out by the FCC. 55

53 Mosher and Crawford, Public Utility Regulation 93-106 (r933); Boulding, Economic Analysis 562-67 (I948). For a more technical account of the problem see Lerner, The Economics of Control I74-99 (I944).

54 There have been two important arguments in the British discussion. One was based on a confusion about the consequences of a natural shortage in the number of available frequency channels. The other, and at present the only argument of any significance, is that monopoly can maintain the high quality of British broadcasting and that competition would result in commercialization and deterioration of quality. Coase, British Broadcasting (I950).

55 It is possible that under these circumstances the FCC might still choose only one transmission standard, or that the FCC may, for relatively short periods of time, permit more than one standard to operate and then select a single standard on the basis of public acceptance. 
II

A much more controversial alternative would be to abandon regulation by government fiat altogether and to substitute the market, bringing the market within the standard of "public interest, convenience or necessity." There is nothing inherently strange about this idea. That the phrase was first used in public utility regulation concerned with the peculiar problem of decreasing cost industries need not mean that it must be inseparably tied to choice by government fiat.

The FCC could lease channels for a stated period to the highest bidder without making any other judgment of the economic or engineering adequacy of the standards to be used by the applicant. The FCC would still determine the width of channels, but on the basis of one criterion-the maximization of revenue from the leasing of this scarce natural resource. This determination would be a trial and error process, (like other solutions of economic problems through the market) but there would always be the restraining force on the Commission of maximizing its income. If changes were introduced too frequently, the resulting confusion might reduce the income below the maximum; if changes were made too infrequently for the rate of technological change and other shifts in relevant variables, this also would reduce income. A large amount of unleased channel space would mean that the price had been set too high; if there were more demands for channel space than channels available, it would mean the price had been set too low. ${ }^{56}$

The market solution would follow the logic of the price mechanism in an economy based on free consumer choice.57 A basic premise of an economy organized around free consumer choice is that if a consumer at a given level of income is permitted to exercise free choice in selecting from the goods available in the economy, the combination of goods he chooses will give him the maximum of satisfaction possible at that level of income..$^{8}$ The only way he can be made

${ }^{56} \mathrm{~A}$ similar scheme has been used as the basis for recent theoretical developments in economics which use the price mechanism for the solution of the problem of how to allocate resources rationally in a socialist economy. Frequency channels are a socialized sector of the economy. There is a provision in the Act requiring every licensee to sign a statement that he disavows any property rights in the license issued to him. 48 Stat. 1083 (I934), 47 U.S.C.A. \&304 (Supp., 1950). An elaborate but abstract scheme of this kind is presented in Lerner, The Economics of Control (1944). The suggested plan would give the same results as those achieved in an economy based on Lerner's scheme to the extent that broadcasters-licensees did not behave as monopolistic buyers. This plan has the advantage that the broadcasters are operating in their own economic interests for profit and that its operation is not dependent upon the accuracy with which they follow abstract rules.

57 For a development of this "logic" in a private enterprise economy see Knight, The Economic Organization 6-13, 3I-35 (I933). Lerner, The Economics of Control (I944), develops this "logic" for an economy which is not necessarily based on the private ownership of property, e.g., frequency channels.

${ }^{8} \mathrm{It}$ makes no difference for the purpose of this analysis whether this premise is really at bottom an ethical one or an empirical assumption about the behavior of people, although there is still some difficulty over this matter among theoretical economists. See Little, A Critique of Welfare Economics $69-85$ ( 1950$)$. 
better off economically is by increasing his total income, not by selecting any other combination of commodities for him. ${ }^{59}$ The greatest social benefit will result if factors of production (including frequency channels) are used by producers who can pay the most for them..$^{60}$ The price which producers are willing to pay depends on the increase in profits which he expects from the addition of a factor of production; this in turn depends on how much the public is willing to pay for the product imputable to the added factor of production. ${ }^{6 r}$ In the case of television, the consumer does not pay directly, but the same results are reached when the amount advertisers are willing to pay is taken into account, because that depends on the size of the audience the advertiser can expectin the end, on what the public chooses.

The alternative to the assumption that people get a maximum of satisfaction through free choice in selecting goods must necessarily involve some decision as to what the people should have. There is an indefinite number of possible criteria depending upon the predisposition of those who are setting the standards. If the validity of free consumer choice as the ultimate criterion of what is good for the consumer is accepted, then the presumption should always be against any administrative act which substitutes the judgment of the administrative agency for such free choice. An administrative agency which intends to use its own judgment should be able to show that under the particular circumstances, free consumer's choice will not work out as predicted by the economists' theory of consumer behavior. ${ }^{62}$

The most important disadvantage of multiple standards is that all sets will

59 Lerner, The Economics of Control 7-22 (I944).

${ }^{60}$ This statement is true only if income is distributed in a way that may be considered ethically justifiable by the community. Consult Knight, The Economic Organization 65-66 (I933). However, a departure from the price mechanism because of an ethically unsatisfactory distribution of income must then be justified on the ground that the departure will result in a more favorable distribution of income. One argument of this type has been made with respect to broadcasting regulation. See note 62 infra.

6x Consult Knight, The Economic Organization 65-66, roo-I26 (1933).

${ }_{62}$ There is one possible justification for substituting the discretion of an administrative agency for free consumer choice even if it is agreed that individuals are the best judges of what is good for them, and even if it is agreed that free consumer choice under existing conditions would work out as predicted by the economists' theory of consumer behavior. It is possible that the distribution of income is such that the weight given in the market to the choices of different individuals is considered ethically unsound. This argument seems to have been the basis for some of the Commission's policies. The argument took a rather unusual form. The problem was not that income was distributed inequitably among consumers of broadcasts but between two different classes: broadcasters and listeners. The broadcasters were not using broadcasting as a commodity to be sold to consumers (or as a commodity to sell advertisers which is the usual method under the American system of financing broadcasting) but instead were using broadcasting time as a final commodity to air their own political views. To the extent that this is true, arguments can be made for regulation by a commission independent of any of the arguments analyzed in the text. See Old Standards in New Context: A Comparative Analysis of FCC Regulation, I8 Univ. Chi. L. Rev. 78 (I950), for a discussion of the development by the Commission of criteria for the regulation of editorializing by broadcasters. 
not necessarily receive all program transmissions. This will undoubtedly seriously reduce the value of receiving sets to the public and the result may be that people will buy fewer sets. Manufacturers may decide to market sets that will receive all or most transmissions. At present, it is technically possible to build a set that will receive two different methods of transmission, but if a third is added, it will probably have to be at the expense of a loss of efficiency in reception of one of the three..$^{6}$ It is possible that these difficulties would be quickly overcome under the economic pressure of an increase in profits, but the sets will be more complex and therefore more expensive. This would also reduce the effective demand for sets to some extent.

It is possible that broadcasters and manufacturers, even in a competitive market, will find it in their own economic interest to adopt a single system. This could happen without any type of agreement, as an outcome only of the pressure to increase profits. There may be relatively brief periods of innovation when many standards will be tried, followed by longer periods in which the standard that was most successful with the public in the brief competitive struggle would be adopted. The short period of innovation would probably affect only the top of the income pyramid-that section of the public which is most ready and able to bear the risks of innovation. But the final result of a more flexible rate of innovation may not be a single standard, or the period during which there are multiple standards may be long enough to inconvenience large sections of the public. In that case it is not easy to determine which will be greater: the losses to the public because sets will not receive all program transmissions or the gains to that part of the public which, if permitted to choose freely, would choose a more rapid rate of innovation. Any answer to this question would depend on how inconvenient it would be for consumers to have a set which only received some program transmissions, how much more expensive a set which could receive several different methods of transmission would be than a set which could only receive one, and to what extent consumers would benefit from a less rigid rate of innovation. Relative costs can be compared to some extent when the information becomes available, but the other two variables are not measurable and any evaluation of their importance will probably depend more on the social values of those making the comparisons than on empirical information.

There is yet another difficulty which may be introduced by a more flexible rate of innovation. The rate of obsolescence of receiving sets may be greater than individual consumers would choose for themselves. ${ }^{6}{ }^{4}$ If an individual consumer can choose freely, he will take advantage of innovations at a rate which is optimum for him. But in the case of television sets, his choice would be limited by the discretion of broadcasters in choosing methods of transmission. The

${ }_{63}$ The Present Status of Color Television, 38 Proceedings of the I.R.E. 980, 98I (r950).

${ }^{64}$ This argument is made by CBS. Memorandum of Columbia Broadcasting System, Defendant-Intervenor, Radio Corp. of America v. United States, 6 RR 2073 (I950). 
value of a set depends on what programs it can receive and this is outside the control of an individual set owner. If broadcasters change their methods of transmission frequently so that existing television sets can no longer receive any or most programs, the sets lose value through no choice of the consumer.

But the interest of broadcasters will be in having as low a rate of obsolescence of receiving sets as is compatible with maintaining or improving their competitive position with other broadcasting companies. A broadcaster's economic interest is in receiving the maximum amount of revenue from advertisers for the use of broadcasting facilities, and the amount advertisers are willing to pay for broadcasting time will depend to a large extent on the size of the anticipated audience. A rate of obsolescence so rapid that it would reduce the total number of sets without increasing the number of set owners whose sets receive the transmissions of a particular broadcaster would not be in that broadcaster's interest. It is doubtful whether broadcasters would ever favor any innovation that would result in the obsolescence of a large number of sets in the hands of the public unless the innovation were of the first importance and could be expected eventually to replace all existing sets.

Manufacturers will have an economic interest in a high rate of obsolescence as soon as the television industry reaches a stage where most sales are for replacement of sets or to new families which are just setting up households. This is true of all producers of consumers' durable goods, and manufacturers would have less control over the situation in the television industry because of the conflicting interest of broadcasters. A broadcasting company such as RCA which also manufactures and sells receiving sets will have to determine a policy which will maximize its total income from both sources. Whatever the decision of a company in this position, it will have to be for a lower rate of obsolescence than would be true in an industry where producers have a relatively untrammeled interest in a high rate of obsolescence of their product; e.g., automobile manufacturing.

Even if the rate of innovation is much closer to optimum under multiple standards than under a single standard, after making allowances for the adverse effect of a higher rate of obsolescence, new difficulties may be introduced by the adoption of multiple standards. The total demand for receiving sets at any one time may be less because of a loss in value to consumers due to the fact that all sets do not receive all transmissions, or because of the discouraging effects on some consumers of a rapid rate of obsolescence. The fall in demand might mean higher prices because no manufacturer would be able to take full advantage of the economies of scale in the production of receiving sets. The price at which he can sell his product might begin to fall long before he had reached a point where the cost of producing an additional unit stopped falling. But if there are no appreciable economies of scale, and this seems to be the 
situation in the television set manufacturing industry, this problem may never become important. ${ }^{65}$

The quality of programs may be adversely affected by a fall in total demand for receiving sets. ${ }^{66}$ Advertisers are willing to pay high prices for broadcasting time and elaborate programs because of the size of the audience which they expect to reach. A fall in the total number of sets in use will reduce the size of this audience. Multiple standards alone and the fact that all receiving sets cannot receive all programs may also have some adverse effect on program quality. Under existing conditions of a single standard, an advertiser's potential audience can only tune in on one program at a time, but an advertiser supplying a program of particularly high quality can expect that a greater than average audience will tune in on the station from which he is broadcasting. If there were multiple standards, and if all sets could not receive all programs, this would not be possible. A set owner would be limited to the broadcasting channels which his type of set could receive. An advertiser presenting an exceptional program could expect a greater than average audience, but only from those sections of the public owning sets capable of receiving the broadcasting signals he is transmitting. Obviously this difficulty would be overcome if manufacturers marketed sets that could receive all broadcasting transmissions or if competition between broadcasters resulted in the adoption of a single method of transmission after a relatively brief period of innovations.

The main obstacle to a serious consideration of alternatives to present methods of regulation is the strangeness of the new ideas. The strangeness seems to be accentuated by the fact that the change would be from regulation by government fiat to regulation through the market process. It is easier to make changes in the other direction because the idea of economic "control" is historically associated with regulation by government fiat. It is still a relatively new notion that the market process can be used as a method of conscious control. There would also be opposition from the groups which have acquired a vested interest in the present methods of regulation. Established manufacturers would not like to assume the new risks involved in predicting what the consumer will choose. Established broadcasting companies would certainly not like to pay large competitive rents to the federal government to lease frequency channels (assuming the complete market alternative is attempted). The public, accustomed to receiving all broadcasts on a single set, would probably be disturbed by the idea of a change and might overlook possible benefits from the greater amount of flexibility introduced. ${ }^{67}$ But despite these obstacles, the

${ }_{65}$ See Lerner, The Economics of Control $x_{4} 6-63$ (r944).

${ }^{66}$ This argument is made by RCA against the adoption of an incompatible system. Reply to Motion to Affirm at 3, Radio Corp. of America v. United States, United States Supreme

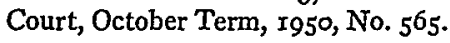

${ }_{67}$ The recent development of two additional competitive speeds for phonograph records is roughly analogous to the problem of multiple standards. Standard phonograph records were 
present system cannot convincingly resolve issues like those involved in the color television controversy. This situation presents a powerful inducement for considering the alternatives.

made of shellac and operated at 78 revolutions per minute. In May 1948, Columbia Records (CBS) introduced a $33 \frac{1}{3}$ r.p.m. record made in $10^{\prime \prime}$ and $x 2^{\prime \prime}$ sizes of vinylite plastic. RCA Victor followed shortly with a 45 r.p.m. vinylite record in $6^{\prime \prime}$ and 7 " sizes. The public reaction to this kind of competition is difficult to estimate with finality, but there was certainly a great deal of irritation and confusion at first. See 168 Nation 523 (May 7, x949); Business Week No. $1075,80-84$ (April 8, x950). One manufacturer was reported to want the Department of Commerce to intervene to avoid the confusion. I68 Nation 523 (May 7, I949). But there is no question that the new records have advantages and that there has been considerable public acceptance. At present the situation may be crystallizing with the $33 \frac{1}{3}$ r.p.m. records more suitable for classical music where long playing records have a decided advantage because of the greater length of the pieces, and the smaller 45 r.p.m. records more suitable for popular music where the pieces are shorter. Record players which will play one of the three speeds, and those which will play all three speeds, are both being sold. 